\title{
Urban energy futures: a comparative analysis
}

\author{
Graeme Lang
}

\begin{abstract}
No contemporary major city is sustainable, with current population and levels of consumption, beyond the fossil fuels which have facilitated what has appropriately been called "high-energy modernity." At present, there appears to be no realistic possibility in any major city of replacing most of the energy from fossil fuels with renewable energy. Even in cities which could get most of their electricity from renewables, there is still a heavy reliance on motorized transport of people, goods, and food into and around the city. There does not appear to be a way to power and reproduce these fleets of vehicles solely with renewable energy, and most cities are not sustainable at their current size and density without them. But cities and regions vary in sustainability depending on local renewable energy sources, hinterland food production, population, extent of urban sprawl, and access to water-borne transportation. This paper identifies the features of more sustainable versus less sustainable cities, with examples from Asia, the Americas, and Europe. Case studies of two cities-Hong Kong and Vancouver, B. C.- - are used to illustrate the analysis.
\end{abstract}

Keywords: Sustainability, Energy, Cities, Fossil fuels, Renewables, Urban futures, Hong Kong, Vancouver, B.C.

\section{Introduction}

Cities have been dramatically transformed since the beginnings of the fossil fuels era in the nineteenth century. The energy density and transportability of coal and oil facilitated the growth of megacities, increasingly linked to each other and to the resource hinterlands which sustain them with vehicles powered by fossil fuels. Massive flows of resources, goods, and people into and among these cities are the hallmark of what has been called "high-energy modernity" [1]. Indeed, it appears that "modern society would crumble without these fuels" [2]. But we can already foresee the end of the fossil fuels era, and there are credible estimates that this will occur, at least for oil and gas, during the decades after $2050[3,4]$. If this is correct, there will be huge consequences for cities, and for the global economic systems in which they are embedded.

Unfortunately, almost all of the planning and projections in government, academia, and NGOs extend only to about 2050, and planning horizons are often much shorter. Politicians in electoral democracies focus on

Correspondence: graeme.lang@gmail.com

Advisory Committee, Department of Asian and International Studies, City University of Hong Kong, Kowloon, Hong Kong policies around election cycles of 2, 4, or 6 years. Government bureaucracies and urban planners may extend their planning to 15 or 20 years, or longer for major infrastructure projects, but almost never past 2050. Environmentalists may project out to the 2030s or the 2050s in discussing climate change trends and strategies. All of this thinking, planning, and activism stops short of what could be the biggest crisis for cities in the latter half of the twenty-first century, with even larger consequences for most cities than climate change: the end of the era of cheap fossil fuels.

Although unpredictable innovations and scenario-disrupting political surprises are bound to occur $[5,6]$, it is important to consider the most probable scenarios. A commonly used calculation for prioritizing contingency planning is probability $\mathrm{X}$ severity. The probability of the depletion and eventual unavailability of oil and gas during this century, and of high-quality coal by the early twenty-second century, is close to a certainty. The severity of impacts resulting from the decline of fossil fuels is very high for most cities, if renewables cannot fill most of the gap. To date, in most cities and regions, renewables are very far from providing supplies of energy equivalent to what is currently derived from fossil fuels, 
and there are few plausible scenarios in which renewables technologies could achieve this goal, as I will argue below. But how far into the future should we extend the analysis?

In this paper, I will take the long view, and extend the issue of the sustainability of cities beyond 2050 into the late twenty-first century. First, I briefly review the development of "sustainability" discourse since the 1970s, and the increasing concern with energy futures since the 1990s. Then I summarize the evidence and analysis, from this literature, that fossil fuels will be depleted and increasingly costly or unavailable during this century, and that renewables in most regions cannot replace more than a fraction of this energy. Then I compare cities on their prospects for sustainability, with case studies of two major global cities. Finally, I consider some impacts on cities of energy depletion in the regional and global systems in which they are embedded.

\section{The rise of "sustainability" discourse, and growing concern about energy}

The post-WWII economic boom in Europe, North America, and eventually in East Asian countries such as Japan and South Korea, combined with rapid technological innovation throughout the period from the 1950s to the 1990s, led to widespread optimism about the future of industrial societies. However, from at least the early 1970s, there has been growing concern about pollution and environmental degradation. The publication of The Limits to Growth [7] raised the discussion and debates to the global level, including questions about the long-term future of industrial societies in a world of unprecedented population growth, rising consumption, and finite resources. Some of these discussions led to the concept of "sustainable development," a theme developed in the 1980s which has persisted in many realms of discourse up to the present.

Most of this "sustainable development" discourse proposed that with enhanced efficiency, reduced waste, more careful conservation, and better state regulation, it would be possible to maintain and even raise standards of living in well-managed modern societies for the foreseeable future [8]. "Sustainable development" discourse was thus still essentially optimistic. Most of this analysis assumed that modern societies are robust and versatile. Economists argued that societies could find substitutes for depleting resources using the power of the market to generate new technologies. Pollution and environmental degradation could be mitigated through "ecological modernization." Continuing economic growth was both possible, and desirable. This was and for the most part still is the dominant worldview in business, politics, and academia. But some scientists focused on and highlighted unsustainable exploitation of resources such as forests and fisheries, and investigated the social and political conditions under which such resources can be conserved [9]. "Sustainability" was increasingly viewed as contingent on social and political arrangements, and by no means assured by markets, or by government regulations.

From the late 1980s, scientists began to call attention to the evidence for climate change caused by human activities such as burning fossil fuels and deforestation, and to the potentially serious consequences under "business as usual" projections. By the late 1990s, there were movements at global, national, and local levels to reduce emissions from burning coal and from clearing forests, and climate change had risen to the top of the global agenda in regard to environmental impacts of human societies.

Meanwhile, some advocates of the benefits of life in large cities argued that high-density living is helpful for climate change mitigation, particularly in reducing per capita energy consumption and facilitating greater use of public transit-but typically these analysts assumed a continuing supply of accessible and affordable energy, and were mainly concerned with reducing waste in energy consumption [10, 11]. However, in the 1990s and early 2000s, other analysts began to point out that oil and other fossil fuels were the master resource for modern economies, that most of the remaining oil would probably be gone before the middle of the twenty-first century, and that an energy crisis was looming in the near future, and certainly after 2050.

Some of this work was grounded in ecological perspectives, highlighting the dependence of any human society on sustainable inputs from nature $[12,13]$. Other analysts were impressed and influenced by the work of some scientists and oil industry geologists. M. King Hubbert had developed methods of estimating future oil recovery on the basis of the history of oil discoveries, and had striking success in predicting the eventual peak of oil production in the USA in the early 1970s, and the inevitable decline in production during the 1970s and 1980s [14]. Later oil industry analysts used advanced versions of Hubbert's methods and the data on oil discoveries and production around the world to forecast an imminent peak of production [3], with estimates of peak production and the beginnings of the decline in production, ranging from 2005 to the 2030s.

The data and analysis which supports these conclusions have been presented in many books and articles (e.g., $[2-5,15-30])$, including the use of similar methods to predict peaks in production of natural gas and coal (e.g., [4, 29]). Richard Heinberg's books The Party's Over [18] and Powerdown [19] were probably the most influential in the growing literature on "peak oil" and its implications. James Howard Kunstler [31, 32] and John Michael Greer [33-35] also published a series of 
influential books during this period on the profound implications of the coming energy crisis for contemporary modern societies. All of these analysts predicted economic decline and greatly reduced standards of living, and suggested that a future population collapse, as envisioned in worst-case scenarios in The Limits to Growth $[7,36]$, was also possible and perhaps in the longer term even inevitable [37]. One of the themes from these works was the need to abandon "economic growth," as a political and economic imperative, in a world of finite and diminishing resources $[20,36]$, and some economists began to explore what this would mean for industrial societies [21, 38, 39]; others proposed awkward terms such as "economic undevelopment" [italics sic] [37] and "degrowth" [22].

The implications of diminishing energy resources, for most major cities, are profound. Since the late nineteenth century, fossil fuels became a master resource for urban economies and for regional and global production and trade. Cities could not have grown to their current size, population density, and economic complexity without these fuels $[1,2,32]$. The energy which makes modern cities possible is not just from the production of electricity-which we now take for granted and without which city life seems unimaginable for those who have lived in electrified cities-but also from the production and distribution of the fuels needed to carry food and other goods into and around cities, mostly by trucks burning fossil fuels. Cities are not sustainable at their current scales without the transportation of goods and food in those trucks, and it does not appear to be possible in most regions to replace more than a fraction of this transportation energy with biofuels or electric vehicles [24].

Heinberg, Kunstler, and Greer noted the unsustainability of major cities and most urban occupations as the depletion of fossil fuels eventually disrupts and degrades economies built on cheap energy. Their prognoses focused mainly on the inevitable relocalization of production and trade as fossil fuel energy dwindles, and the need to build resilient local communities where the skills to grow food and to make and repair the necessities of everyday life are revived within local economies. The "Transition Towns" movement which started in the UK reflected this vision of the future beyond fossil fuels [40].

The growing focus on energy transitions has been largely a response to the problem of reducing carbon dioxide $\left(\mathrm{CO}^{2}\right)$ emissions to mitigate climate change, and not because of concerns about the long-term depletion of fossil fuels. However, within the last few years, there has been a notable increase in academic conferences, workshops, and research programs devoted to sustainable energy transitions for energy security reasons, along with associated concerns about energy poverty and energy justice. What appears to be lacking in most of this work is the analysis of what happens to cities in the post-fossil fuels future.

Cities are key nodes of cultural and social complexity, and of scientific and technological innovation. This civilizational superstructure is supported by surpluses of food and other goods, limited only by the quantity of such surpluses which a society can generate. The loss of fossil fuels could have a large impact on the capacity of a society to produce and distribute food and other goods. If renewables cannot fill the gap, urbanized societies will have to shed population and complexity. However, the fates of cities depend on their assets and characteristics within their own regions.

Are some cities more "sustainable" than others? The most extensive analysis of this question is by John W. Day and Charles Hall for a sample of cities in the USA, in America's Most Sustainable Cities and Regions [2]. In addition to energy supply, they analyze the sustainability of selected cities in terms of population (megacities are less sustainable than some smaller cities and towns in regard to per capita supply of food, water, and energy), fertile soil, extensive arable land around a city (the ratio of arable land to population is the key factor), reliable supply of water, lack of dependence on tourism, a producer-based local economy with local production of many goods and services consumed locally, and extent to which a city is vulnerable to climate change impacts such as drought or rising sea levels. Then they ranked ten US cities into the categories of "likely sustainable," "moderately sustainable" (with much hard work and adaptation), and "severely compromised sustainability" (the current state of the city or region is almost certainly unsustainable) [2]. They find that large cities in the USA included in their analysis are unsustainable beyond fossil fuels - that is, beyond the time when food, goods, and/or free-spending visitors can easily be brought into the city to sustain the local population. Only a few small towns in prime agricultural regions, such as Cedar Rapids, Iowa, turn out to be potentially sustainable. The authors conclude that none of the major cities reviewed in the book can maintain their current populations beyond the depletion of fossil fuels. The book is very important, and this analysis should be replicated for the cities in other countries and regions. One of their conclusions is that "cities will probably have to become smaller and reintegrate with their local regions" [2].

Before we proceed further, it is necessary to consider the possibility that most of the energy from fossil fuels can be replaced by renewable energy sources such as wind, solar, and hydro. Can the fossil fuels be replaced by other sources of energy which could sustain contemporary cities at a level approximating their current populations and levels of complexity? If not, what proportion 
of the energy currently derived from fossil fuels can be substituted by renewable energy? If the proportion is something like $70-80 \%$, then the transitions can probably be managed in many cities with common "sustainability" initiatives for increasing efficiency and reducing waste. If the proportion is more like $20-30 \%$, and there appears to be little or no prospect of replacing all of the energy currently derived from fossil fuels with renewables as a number of analysts have argued $[2,5,18,24$, $31,33,41,42]$, then cities face a bleak future of decline and of reductions in population and in standards of living. The impacts will be even more severe for cities which are dependent on global networks of production and trade which in turn depend heavily on fossil fuels. So: can renewables save cities?

\section{Problems with sources of "renewable" energy}

Despite rapid growth in the production of wind turbines and solar panels, these sources of "renewable energy" electricity provide only a fraction of global energy consumption [43], and it does not appear that there is any prospect that solar or wind can be scaled up and installed in sufficient quantities to keep most cities reliably electrified. There are geographical and seasonal constraints on these sources of electrification in most regions, and very few cities could be fully electrified throughout the year using only local or regional renewable energy. Solar power through solar thermal plants or through hectares of solar PV panels is best installed in deserts. Some countries in the Arabian peninsula are beginning to build these facilities, using revenue from sales of oil [44]. These kinds of installations have also been built in desert regions in the USA and southern Europe, and could be built in North Africa. But there are few regions where such facilities can be built to serve nearby major cities. The problems of energy storage and maintaining baseload power are also not close to resolution for wind and solar in most regions unless other sources of baseload energy supply such as hydro or nuclear are available. Even the most optimistic estimates of future RE production of electricity (approaching 50\%, globally, by 2050? [45]) require major expansions and cost reductions in battery-storage systems, and still require natural gas and nuclear power to supplement the electricity supply from renewables.

In a few regions such as in Europe, it is possible to imagine a continent-wide grid which collects all of the electricity generated across Europe and North Africa by expanded solar and wind installations, and which stores temporary electricity surpluses from across the region by pumping water uphill behind dams (in this case, in Norway) for later release into turbines when demand exceeds supply. But this requires a number of large hydroelectric dams (available for Europe only in Norway), major expansions of expensive offshore wind installations and on-shore solar PV arrays, and massive expansion of the transmission facilities across the region to get temporary electricity surpluses from wind and solar to the Norwegian dams, and back into cities throughout the region when demand exceeds RE supply [46]. It has been estimated that $20-25 \%$ of the surplus electricity from such a system is lost in the process of pumping and recycling water [47]. Even if such a system could actually work without the need for any baseload power from nuclear or fossil fuels power plants, the high cost and the logistical and political problems are huge hurdles.

There is also the problem of replacing highly engineered technologies such as giant wind turbines beyond fossil fuels. The use of the "rare earths" such as neodymium in these wind turbines, and the limited global sources for such materials, is only one of the physical constraints. The industrial-scale manufacturing and transportation of these massive facilities is another constraint. If a "renewable energy" installation cannot be replaced at the end of its life cycle using only renewable energy, it is not really "renewable" beyond the working lifetime of the equipment. Estimates of lifespans for wind turbines and solar arrays vary depending on location, weather stresses, and engineering, but are generally no more than about one human generation. The lifespans of giant wind turbines in most locations are estimated to be $20-25$ years [48].

Lifespans of hydroelectric dams are several times greater-estimates vary from 80 years to more than 100 years-but lifespan of a dam depends on the rate of sedimentation behind the dam, settling and possible cracking of concrete, stresses such as floods, and durability of the turbines. Many dams also depend on spring melt into rivers from snowpack and glaciers, and in some regions climate change may deplete the water supply for dams during the spring and summer. Nevertheless, hydroelectric dams, once built, provide the best prospects for longer-term reliable electricity.

For those cities or regions which are able to maintain renewable energy installations while nearby areas have not done so, the costs may increase substantially as a result of theft of components by scavengers and armed gangs, and the need to protect renewables facilities such as wind turbines and solar arrays against such thefts, a problem which is already occurring in some areas $[49,50]$.

There are research groups experimenting with novel technologies for producing "renewable" energy, funded by venture capital, or by government programs such as the Advanced Research Projects Agency-Energy (i.e., ARPA-E) in the USA [51]. Experiments and possibilities include kelp farms, cultivation and genetic tweaking of 
algae, super-giant wind turbines, air-borne tethered wind turbines, and mining of deep-ocean methane hydrates. Since the storage of electricity in lithium-ion batteries does not appear to be a feasible solution for large-scale applications, there are also various schemes for other methods of storing energy from surplus solar or wind-generated electricity, such as pumping water uphill behind dams, or compressing air in salt domes or in abandoned oil wells. However, up to the present, it seems that there are no technically feasible solutions for producing or storing surplus electricity from "renewable" sources which can be scaled up and implemented for most major cities. Producing hydrogen with surplus electricity, as a way of storing energy, also apparently cannot be scaled up (at present) and does not appear to be a feasible solution [41].

\section{Nuclear power plants}

Nuclear power plants currently have a lifespan of 40 to perhaps 60 years before they have to be decommissioned, and produce almost no air pollution or carbon dioxide during normal operations. There are more than 400 nuclear power plants worldwide, and many countries and regions get a substantial portion of their electricity from such power plants (e.g., as of about 2010: Canada: 15\%; UK: 18\%; USA: 20\%; Sweden: 37\%; Ukraine: 49\%; France: 75\%) [52]. Properly managed and regulated, they can help to "keep the lights on" during the inevitable transitions to low-carbon economies in the future $[53,54]$. To build nuclear power plants requires mining and energy-intensive manufacturing and construction. India, China, and Russia are building a number of new nuclear power plants. If small or "modular" nuclear power plants become technically feasible, reliance on nuclear power for electrification may grow rapidly over the next 50 years. Fast-neutron reactors may also be deployed in some countries in the coming few decades. Some designs of these reactors are capable of producing more fuel than they use (so-called breeder reactors). At least ten countries are individually or collaboratively working on development of these "Generation IV" reactors [55], and their advocates, including scientists such as James Hansen [54], highlight their potential as sources of "clean" energy to replace coal and natural gas. (I am ignoring the prospects for nuclear-fusion power plants, since the technical obstacles are formidable, and despite decades of work, success always seems to be 50 years in the future; it may never be a feasible method of electrifying most cities).

However, nuclear power plants may be very difficult and costly to build in the post-fossil fuels era, and by the early twenty-second century, we may see the last of these electricity producers as remaining plants are decommissioned. In some countries such as the USA, and across Europe, most of the nuclear power plants are aging and will have to be decommissioned and replaced in the coming few decades [24]. Indeed, the number of nuclear power plants in the world has declined slightly during the past decade, as more plants are decommissioned than are being built [56]. It would take a major political commitment to nuclear power plants to change this outcome for a particular city or region, and up to the present, public resistance to building nuclear power plants has increased in most regions, especially since the Fukushima Daiichi nuclear accident following the tsunami in 2011.

Modern cities need electricity as much as they need water and food, especially when a majority of the population lives and works in high-rise buildings. Pumps, elevators, refrigeration, lighting after sundown, electrified mass transit, data storage and retrieval, and electronic communication would cease to function without continuous and reliable electricity. Support for nuclear power plants may grow as it becomes increasingly apparent, in the late twenty-first century, that renewables are not going to reliably electrify most cities in the post-fossil fuels era. Some cities may eventually embrace nuclear power, but many regions will not be able to afford nuclear power plants by the time it begins to become urgent to build them. In any case, nuclear power plants currently supply less than $15 \%$ of global electricity production, and there is no realistic prospect that these expensive installations could be built rapidly enough and in enough locations to replace coal or gas for generating electricity.

It is a common view among many economists and even among many environmentalists that somehow technological innovation will rescue modern urban societies from energy shortages in the post-fossil fuels future. But the conclusion that renewables will deliver far less than what we currently get from fossil fuels has been reached by a number of analysts $[2,19,24,33,35$, 42]. Even for electricity, renewables will not replace the decline in energy supply for most major cities beyond fossil fuels.

Besides electrification, the post-fossil fuels city has two key problems to solve: feeding urbanites without the fossil fuels to produce, harvest, and distribute the food [57]; and transporting food, other goods, and people into and around cities without the use of fossil fuel-powered vehicles [24]. Most of the work on "renewables" focuses on production of electricity, but for cities, liquid fuels are equally important. Major cities are unsustainable without the large numbers of vehicles burning fossil fuels to bring food, goods, and people into these cities. The scale of the problem becomes apparent when we look at graphics (e.g., [58]) of primary energy consumption, which includes both electricity and liquid fuels; "renewables"-even if we 
combine solar, wind, and hydro-still offer only a small fraction of the primary energy provided by coal, oil, and natural gas [43]. Can modern cities survive when these fossil fuels are no longer available?

\section{Food for cities}

In the pre-industrial era, most towns and cities relied on food produced within the agrarian hinterland of the city, transported into the city in boats or carts. Fresh foods were only available in season, and towns subjected to harsh winters lived through those winters with stored grain, and by drying, salting, smoking, or pickling some types of food or refrigerating it outdoors or with ice harvested during the winter. Many households within and near towns and cities also kept animals for meat, eggs, and dairy products. Storable grains were transferred into wealthy or imperial cities from more distant agricultural zones, as in ancient Rome, which brought grain to Italy by wooden ships from Egypt and North Africa, and in pre-modern China, where grain and other foods were carried to the imperial capitals by boats along rivers and canals. City size for most other cities was limited by the ability of the local hinterland to provide food for the urban population. Ruling elites and armies typically engaged in coercive extraction of food from hinterland peasants, in the form of taxes, rents, or expropriation. But even coercive food extraction could only support a minority of the population living as city-dwellers or serving in armies. Until the late nineteenth century, a large majority of the settled population in every society was necessarily engaged in food production and related activities.

As fossil fuels were increasingly deployed in production, transportation, and trade, the dependence of a city on its rural food-producing hinterland has been greatly reduced in most cities, and certainly in the largest and wealthiest cities. The global system of producing, harvesting, transporting, and distributing food has been successful during the past few decades in providing a wide range of foods to cities more or less independently of local and seasonal fluctuations in food production in the hinterlands of these cities. But this system depends heavily on fossil fuels for fertilizers, harvesting, transport, and distribution to local urban food markets, and vehicle-travel by urban consumers to those food markets [57].

More recently, and especially during the past 30 years, concerns about food safety and food security have led to a striking rise of interest in relocalizing food supply near and within cities, and to the inclusion of these concerns into urban planning discourse and into local foods activism [59-61]. Some local food activists and planners are aware of the heavy dependence of their food sources on fossil fuels, and support greater local and organic food production within cities and in nearby rural areas partly for that reason. It has also become clear that rising fuel costs and food prices will have the greatest impacts on the urban poor in many cities. Such concerns have led to many local gardening initiatives in poor areas of major cities in developing countries [62], and to attempts in some major cities to find out how much land within the city is actually used or potentially available for growing food [63].

Many activists and planners also support local food for various co-benefits (increasing urban "green spaces," educating students [64], engaging youth and elderly in local community activities, strengthening local -community interactions and bonds, etc.). The discourse about these trends has grown with new terms such as "locavores," "food sheds," "slow food," "food miles," and so on.

Critics of these kinds of initiatives acknowledge the co-benefits but note that "local food" may have a higher carbon footprint than food imported over much longer distances. For example, grass-fed lamb shipped to London from New Zealand may have a lower energy input per pound of meat than grain-fed lamb raised in England and trucked to farmers' markets [65]. Vegetables carried to New York in the winter from California in large refrigerated trucks may have a lower energy input or carbon footprint per pound of vegetables than greenhouse vegetables carried to farmers' markets in New York in small trucks from rural areas within New York state. However, such critiques miss the main point: in the fossil fuel-deprived future, there will simply be no possibility of transporting California vegetables to New York, or New Zealand lamb to London. Most food consumed in the city will have to be local, and apart from storable food, seasonal.

A more fundamental critique of relocalizing food production in and around the city, including such features as community gardens, farmers' markets, vertical farms, hydroponics, and promotion of food production in the immediate rural hinterlands of a city, is that the food produced from these areas cannot feed more than a fraction of the current population of any major city [65]. For megacities, this is indisputable. For example, if it requires about 0.5 ha to feed one urbanite, the "northeast megalopolis" in the USA which includes New York City and Boston would require more than twice as many hectares of farmland as are available on all of the arable land from Virginia to Maine [2]. The arable land would be insufficient to feed the 60 million people in that region even if all of them became vegetarians.

The calculations suggest that varied and intensive agriculture around a much smaller city could sustain a substantial proportion of the current population of the city at some level of basic nutrition. Day and Hall, for example, note that towns such as Cedar Rapids, Iowa, with 
a population of about 250,000, good rainfall and fertile soils, low dependence on tourism, and substantial outputs of goods using local skills, could be far more sustainable than a megacity such as New York City [2]. But this would be the case for smaller cities only if there were no other nearby competitors for that food, and only if the food could be transported into and around the city without fossil fuels. Even Cedar Rapids still gets most of its food from far beyond its own rural hinterland, and it would require major changes in local food production and distribution, and a greater proportion of the population engaged in intensive local farming, to feed the Cedar Rapids population from rural areas around the city. Few current urban dwellers will want to revert to labor-intensive farming for a living, but that is one of the inevitable future consequences of the loss of many current urban occupations beyond fossil fuels $[5,66]$.

Of course, there are many towns around the world which still get their food from their own rural hinterland and from garden plots within the town. Typically, these are relatively impoverished populations which consume few resources beyond what they can procure locally [67], and are largely isolated from global networks of production and exchange. Some of these towns still use draft animals for transportation and for harvesting local food. They would not be much affected by global economic decline in the post-fossil fuels future, provided their location (e.g., on islands or in remote inland regions) protected them from being inundated by emigrants from declining megacities.

But one of the potential consequences of the depletion of fossil fuels, for towns and cities located near forests, is increased cutting of forests to provide fuel for cooking and heating, land for agriculture, and wood for sale into cities. The resulting deforestation can have destructive consequences for local and regional ecologies, such as soil erosion and flooding in nearby rivers, as has occurred in China and Thailand [68]. As cities lose energy from the dwindling of fossil fuels, it is likely that there will be increased pressure on nearby forests. The unsustainability of a megacity will dump some of the population, along with the environmental impacts of their search for food, land, and biomass, into neighboring regions. The gradual depopulation of a major city which cannot sustain the supplies of electricity and food to its citizens will provide many examples in the future of social, political, and environmental deterioration and conflict.

Although megacities will be unsustainable at their current levels of population, some large modern cities will fare much better than others as they shrink and adapt to depletion of fossil fuels. Some good examples can be found in China. Since the 1950s, for example, the Chinese government has attempted to maintain intensive agriculture around the cities in order to keep peasants in the villages and prevent cities from spreading out into their rural hinterlands. Up to the late 1970s, about 75\% of China's population still lived in towns and villages. During the "reform" era in the 1980s, cities were allowed to take over nearby agricultural land under various schemes, to accommodate factories, highways, shopping malls, and new housing estates.

Coastal cities which expanded rapidly by producing goods for the global market, such as Shenzhen, in Guangdong province, largely abandoned local agriculture, replacing suburban farmland with factories, and were wealthy enough to import food from other provinces in China and from around the world. Cities far from the coast such as Chengdu, by contrast, industrialized much slower, and retained much more local agriculture than most of the coastal cities. By the 2000s, Chengdu, in the southwestern province of Sichuan and favored by soils and climate for productive year-round agriculture, continued to get more than $90 \%$ of the food consumed in the urban core from its immediate agricultural hinterland within the Chengdu municipality, while Shenzen got less than $10 \%$ of its food from within its municipal boundaries [69]. Chengdu has recently been expanding into some of its agricultural land with industrial zones and science parks, but it will face far fewer problems in feeding urbanites than cities such as Shenzhen, when it becomes increasingly difficult and costly to bring food to the city over long distances in the latter decades of the twenty-first century. Nevertheless, Chengdu faces the same problem as all other cities beyond fossil fuels: how to get the food from the hinterland into and around the city.

\section{Transportation}

Almost all trucks, cars, busses, ships, and planes currently run on products derived from oil. More than half of the conventional oil will be gone by the middle of this century, and "unconventional" sources of oil will be increasingly expensive to extract. There appears to be no renewable substitute which can replace more than a fraction of this oil. Biofuels derived from corn, sugar cane, jatropha, or camelina will be used in cars, trucks, and busses in some regions, but will not sustain more than a fraction of the current fleets of vehicles. Electric semi-trucks to transport goods and food into and around cities could take some of the load. But the very high cost, heavy batteries, limited load-carrying capacity, and limited range compared to diesel-powered trucks would prevent electric semi-trucks from replacing more than a fraction of the current volumes of truck transport of goods and food into contemporary cities [24, 70], even with devices such as the "platooning" of several large trucks in nose-to-tail convoys [71]. 
Railways carrying trains within cities and between cities are generally durable, and will operate on electricity or on diesel and coal for many decades. Increasing replacement of coal by natural gas and renewables for generating electricity for cities may lead to a longer supply of coal for railways. Coal may still be available for trains or for producing the electricity for electric trains in the first decade or so of the twenty-second century. But even coal will eventually be too expensive for railways except where the railways extend to the remaining coal sources. Cities which get much of their electricity from hydro or nuclear power plants will be able to operate electric trains as long as those facilities can be maintained. Many other cities will have to switch to lighter vehicles.

The lack of sufficient fuels to support the industrialized processes of vehicle manufacture will lead to an increasingly decrepit collection of vehicles in most regions. The cannibalizing of older vehicles for parts, and growing employment in vehicle repair, will keep the reparable cars and trucks on the road for decades as long as fuel is available. But most societies will be unable to support the volume of vehicle transport which is common in and around most cities in the contemporary world.

The most important problem for vehicle-dependent cities has often been conceived as the dependence of commuters and shoppers on private cars to get them around a city [72]. But the more serious problem is the transportation of food into a city from surrounding regions, and the distribution of food to all of the stores, malls, and markets where people buy food. In a sprawled megacity, it will be difficult to accomplish this key function without powered vehicles.

The problem for vehicle-dependent cities is not just fuel for these vehicles, or maintaining the industrialized manufacturing needed to produce the vehicles, but also the maintenance of extensive road networks without the bitumen to produce asphalt or without the heavy equipment, and funds, to use concrete [24]. The most durable roads last about 50 years [73]. Most roads built with asphalt or concrete have shorter lifespans-from 10 to 20 years [24] - and require more frequent repair, especially in cities and on highways subjected to freezingand-thawing conditions during the winter, or to heavy truck traffic. Eventually, most of the roads in regions subject to harsh winters may become too degraded for most vehicles [24, 31], as municipalities increasingly lack the funds, fuels, and heavy equipment to keep roads in good condition.

Cities which have sprawled far into their hinterlands with low-density residential and commercial buildings, linked through networks of roads and highways, will progressively lose the ability to support these sprawled urban and suburban populations with food, or to transport people between homes and workplaces [24]. Highly vehicle-dependent populations such as in Los Angeles, Dallas, Toronto, or London will be hopelessly unsustainable beyond fossil fuels without the importing of biofuels from other regions. But few food-growing regions will be willing to curtail food production in order to grow biofuels for export to overseas cities. When fossil fuels become scarce or unavailable, large parts of these sprawled and vehicle-dependent cities may become depopulated and decrepit.

Air travel will be even more severely affected than travel by ground-based vehicles. Global commercial aviation accounts for about $5.8 \%$ of the global consumption of oil-about 5.6 billion barrels of oil in 2017 [74], not including fuel consumed by the military. Jet fuel (basically, kerosene) can be produced from "second-generation" biofuels (e.g., jatropha). But it would require an area of land several times the size of France to replace the kerosene currently consumed by global air travel with kerosene produced from jatropha. The original hope for biofuel sources such as jatropha was that the plant could be grown on marginal and non-agricultural land, providing employment for jatropha farmers and supplying the aviation industry with a renewable and sustainable source of aviation fuel. Oils from jatropha and other non-food crops can in fact be processed into jet fuel-although the energy return on investment (EROI, i.e., the net energy after subtracting the costs or energy expended in producing that energy) is much lower than for kerosene derived from oil-and this fuel has been tested successfully as a "drop-in" fuel by a number of airlines, in combination with petroleumbased jet fuel.

However, after extensive experiments on marginal land, it appears that jatropha is not very productive in marginal soils lacking irrigation. It produces best results on well-watered fertile soil, but most such land is already used to grow food. Airlines will be reluctant to buy biofuels which have displaced and reduced food production [75]. Limited available marginal land for jatropha production in China turned out to be a problem [76], and attempts in India and China to grow jatropha for biofuels have apparently been largely abandoned [77]. There are marginal lands in the USA which could be used to produce cellulosic biofuel [78], but such lands still require fertilization, and in any case could produce only a small fraction of the biofuels required to replace fossil fuels. Algae have been proposed as a possible source of biofuels, and experiments with algae continue, such as at Arizona State University and other research institutes. But up to the present, it does not appear that oil production from farmed algae can be scaled up to produce fuel to sustain mass air travel.

Sugar cane in Brazil can be processed into ethanol, and this fuel is used widely in Brazil in vehicles and in 
light propeller-driven aircraft. (The EROI is higher from sugar cane than from growing corn to produce ethanol in the USA). Those light planes will still be flying for some time after the end of mass air travel in jet aircraft. But these small planes, flying lower and slower and with lighter loads, will not replace the global fleets of jet aircraft. Even these light aircraft can probably not be produced without an industrial infrastructure of mines, factories, and trucks.

It is of course possible to produce aviation fuels from coal, or from complex processing of biomass [79], but there is a low energy return (EROI) considering the energy required to convert coal or biomass to liquid aviation fuels suitable for jet aircraft. The increasing resort to coal for aviation fuels may be inevitable, as kerosene from oil becomes increasingly expensive and eventually unavailable. But the energy costs in producing these fuels, and the many environmental costs of mining and transporting poor-quality coal, may inhibit this "solution" to future aviation fuel shortages. In any case, the dwindling of the production of coal, probably by the early twenty-second century, provides an inevitable limit on coal-to-liquids processes, and the use of biomass or other wastes cannot be scaled up to replace the quantity of oil-based kerosene used in contemporary global aviation. By the late twenty-first century, the fossil-fueled industrial infrastructure for producing large-body jet planes may also be in terminal decline.

It seems therefore that the global aviation industry is unsustainable beyond fossil fuels [47]. Toward the end of the twenty-first century, if this analysis is correct, air travel "will become the preserve of the wealthy and government" [80], and eventually even that travel will be forced back into smaller propeller planes which do not require kerosene and can run on ethanol or similar biofuels. We may also guess that the military in some countries with large air forces, aligned with militarysupporting political elites, will aim to gain control over the remaining major oil reserves. But oil available for commercial aviation will dwindle, and eventually become too costly for mass air travel. Cities currently depending heavily on tourism in which most of the tourists arrive by plane will lose the flow of plane arrivals, along with the service industry jobs currently generated by mass tourism.

Of course, tourists can travel to some desired destinations by boat, by rail, by horse or horse-drawn carts, by camel, or by land vehicles powered by biofuels. If a city also has networks of canals throughout the city which can be used for water transport, even better. If a city is culturally lively and diverse, and is linked by waterways to other nearby cities which are still prosperous enough for some people to travel by boat to livelier destinations for recreation, the city can benefit from tourism-but at a tiny fraction of the current rates of tourist arrivals by jet airplanes, cruise ships, or busses. The flow of tourists will be much reduced even for cities which provide the most favorable conditions for tourist arrivals in the post-fossil fuels era.

Primate cities such as Paris, Rome, London, Bangkok, and Beijing, which are the administrative capitals of their region and host economic and political activities unrelated to tourism, and which can extract food and goods from wider regions through taxation or other forms of coercion, may get through this transition without a major collapse of the local economy. But even in primate cities, current populations are unsustainable. Tourismdependent cities such as Las Vegas, Orlando, Honolulu, Denpasar, Bangkok, and Hong Kong, along with pilgrimage sites such as Mecca, will shrink even more drastically toward their pre-industrial levels of population.

There are several regions in the world where biofuels derived from sugar cane or other plant material will make it possible to support powered vehicles as long as the crops can be harvested, processed into ethanol, and the ethanol distributed using only biofuels. Brazil is likely to be able to continue to provide such fuels for at least some powered transportation in some areas of the country. But growing corn for ethanol, without fossil fuels for harvesting and processing the corn, does not seem to be a viable solution for North America, since the EROI is very low and it is questionable whether corn can even be harvested on a large scale without fossil fuel-powered harvesters. There are very few cities and urban hinterlands which will be able to get enough biofuel to sustain the current fleets of harvesters, trucks, and busses.

Water-borne transportation is the most efficient way to move people and goods. For cities located near rivers, canals, lakes, and seacoasts, water transportation will be increasingly important [24], along with all of the facilities which support water transport, including docks, wharfs, and locks in canals and rivers. Boat building from sustainable forestry or from scavenged material will be a growth industry.

Where hydropower or nuclear power can provide a city with reliable power for transportation, electrified transport such as light-rail will be viable into the twenty-second century. Where electricity supply is likely to be restricted by the lack of hydro, solar, wind, or nuclear power, and where transportation into and around a city in boats and barges is not an option, bicycles and tricycles with carts will be increasingly used for commuting and for moving people and goods around a city.

Amsterdam and some other cities already have a bicycle-using culture, and many other cities are adding bike lanes to urban streets, along with bike-sharing schemes run by public or private companies, as in Paris, 
London, Toronto, and many cities in Asia. In some countries such as Vietnam, bicycles have long been used to move goods within cities, and although they have been largely replaced by motorbikes and light trucks, Vietnam is only one generation removed from the heavy use of bikes for goods transport and could resume this practice without much difficulty. In cities where biofuels will not be readily available, the transition to urban transportation without fossil fuels will be easier to the extent that bike transportation has already been well-established.

However, many cities are not well-suited to year-round bike transport. For those cities, walking or use of carts, and use of animals such as horses and donkeys will probably begin to replace vehicle transport in some areas. Animals such as horses and oxen will also increasingly be used for harvesting and transporting food, as in the hinterlands of most cities before the advent of fossil fuel-powered vehicles. Some small farms in the USA and elsewhere are already increasingly using draft animals rather than tractors because of the costs of fuel [81] and there are ethno-religious populations such as the Amish in some rural areas in the USA which still rely primarily on horses and oxen. This of course raises the issue of the land needed to produce fodder for these animals. For the USA prior to the widespread use of tractors and harvesters, it has been estimated that in 1915, about 93 million acres of farmland in the USA was devoted to producing feed (mainly oats) for horses and mules [2]. Little of this land would be available now to produce feed for draft animals.

The breeding and sale of horses and oxen will nevertheless be a growth industry in areas where other modes of transport are limited and where there is good pastureland nearby. Towns, cities, and ethno-religious enclaves which already have a horse culture, little access to rivers or canals, and poor renewable energy resources will find growing markets for their animals and their expertise. This prediction will seem ridiculous to those who think that future technological innovation will rescue and sustain the high-energy urban civilization which flourished during the fossil fuels era. But beyond fossil fuels, cities and their hinterlands are likely to be resorting to much more ancient and sustainable sources of energy, including the use of animals for transportation and for agricultural work such as plowing and harvesting.

\section{"Sustainability" assessments}

It should be possible to produce a "sustainability" assessment for a given city, along with a time-scale for each criterion. A city might be sustainable for centuries on water and soil, for example, but unsustainable beyond fossil fuels in the supply of electricity or transportation for goods, food, and people. Of course, "sustainability" can also be assessed at much larger scales than regions. Global extractions of potentially renewable resources such as fish and forests, and non-renewable resources such as fossil fuels, are already occurring at unsustainable rates [13, 82]. Cities which depend on these resources will not be able to avoid many of the consequences if national and international attempts to control these unsustainable depletions are unsuccessful. However, it is still important for cities to try to analyze the extent to which they can sustain themselves with resources from their own regions or hinterlands. As fossil fuels are depleted, energy supplies and food for a city from its own hinterland or region will be the key resource for sustaining at least some urban life.

\section{Case studies}

In light of the above analysis, I will now review the cases of two cities in which I have lived: Hong Kong, which is hopelessly unsustainable in its current form and population size beyond fossil fuels; and Vancouver, B.C., which is sustainable into the twenty-second century in regard to the supply of electricity, but which will face major changes in transportation, the supply of food, and the mix of occupations, to adapt to the depletion of fossil fuels. It can be useful to compare two cities with quite different profiles if the impacts of those differences on energy-related outcomes can be highlighted and explained in the analysis (e.g., [83]).

\section{Hong Kong S.A.R., China}

Hong Kong, a "special administrative region" (SAR) within the People's Republic of China, has a population of about 7.4 million people. There were only small coastal villages in what is now Hong Kong up to the mid-nineteenth century, but it is now a dynamic and thriving node of commerce, tourism, and trade, and has become by most measures a highly successful "global city." It is a major port for the export of goods from mainland China to overseas markets, and for several decades in the 1980s and 1990s, it also contributed to the rapid economic growth and modernization of mainland China, especially through investment in and supervision of thousands of factories in China's coastal provinces. Despite its apparent success and advantages, Hong Kong will be a very different city by the end of this century. Although the city would be resilient in the face of disasters such as flooding and typhoons [84], it has never been assessed on its resilience in the face of future energy shortages. Analyzing its post-fossil fuels prospects is a useful example of the importance of a long-term sustainability assessment.

The total land area of Hong Kong is about $1,100 \mathrm{~km}^{2}$ but it is mostly mountainous; in the built-up urban core areas, which comprise only about $15 \%$ of the total land 
area, population density is among the highest in the world, which facilitates economical mass transit on intra-urban electrified trains and in several types and sizes of busses. Car ownership-about 50 private vehicles per thousand population-and dependence on cars for commuting and shopping are low, while per capita daily use of public mass transit is very high [85]. Almost all of Hong Kong's residents live in high-rise buildings; it has been estimated that about $50 \%$ of the population live above the 15th floor in such buildings. For advocates of the merits of high-density car-free living in cities such as Hong Kong [10], the city should be a good model. However, Hong Kong is hopelessly unsustainable beyond fossil fuels, and in a hundred years, it will be inhabited by a small fraction of its current population. The reasons are as follows:

Electrification: Hong Kong gets about $75 \%$ of its electricity from fossil fuels (as of 2012, about 53\% from coal, almost all of which is imported from Indonesia [86]); about $23 \%$ of the electricity comes from a single nuclear power plant about $50 \mathrm{~km}$ up the coast at Daya Bay, in China's Guangdong Province. Less than 2\% of the city's electricity comes from renewables, and there is no prospect of substantially increasing this percentage, much less of replacing the fossil fuels with renewables. Wind power around Hong Kong is insufficient, and solar PV panels, even if every rooftop and reservoir was covered with solar panels, could supply only a small fraction of the city's electricity at current levels of consumption. The major hydroelectric dams in China are located far to the north and west of Hong Kong, and their output is fully absorbed by other cities in mainland China. Hong Kong cannot rely on hydropower to electrify the city.

The nuclear power plant at Daya Bay started to produce electricity for Hong Kong in the mid-1990s, and will be retired and decommissioned around 2035. Up to 2010, the plan was to increase the proportion of Hong Kong's electricity derived from nuclear power plants from $23 \%$ at present to nearly $50 \%$ by the 2020 s (replacing coal), but that plan was abandoned as politically infeasible after the Fukushima Daiichi nuclear accident in 2011.

Instead, the new plan is to replace much of the coal consumption in local power plants with natural gas by about 2020; the natural gas would be imported through a long-distance pipeline from central Asia and by liquefied natural gas arriving by ship from gas fields in the region and overseas. In part, this proposed change is a result of pressure on the two local utilities to reduce carbon $\mathrm{CO}^{2}$ emissions and the many other pollutants from burning coal. In part, it may also be related to the long-term depletion of the high-quality coal which the company buys from Indonesia. Indeed, it has been estimated that the depletion of coal reserves in Indonesia might become a serious problem for foreign buyers as early as the 2030s [87], especially since Indonesia is also endeavoring to electrify a larger proportion of the country's villages, and plans to burn more coal in coal-fired power plants for that purpose. The prospects for importing high-quality coal from Southeast Asia to Hong Kong do not appear to be assured or even very promising beyond the next few decades. But the prospects for long-term supply of natural gas in the latter half of this century are not much better than for oil and Indonesian coal, and the only other way to provide longer-term baseload power for the city would be through several new nuclear power plants, which could last until about 2080 before being decommissioned.

The city consumes more than $25 \%$ of its electricity in air conditioning, while the electrified trains only consume about 3\% [88]. Air conditioning only became widespread in Hong Kong in the last decades of the twentieth century. As difficult as it will be for residents to give up most of the air conditioning in the very hot and humid summers, it is probably inevitable.

Beyond fossil fuels, Hong Kong will have only a small fraction of the electricity which it currently consumes. Unless additional nuclear power plants are built, water pumps, sewage systems, elevators, and of course air conditioning will be available only intermittently or will not function, and many buildings may eventually be uninhabitable above about the tenth floor. When this becomes apparent to planners and citizens, perhaps the political will to build additional nuclear power plants will materialize. It is by no means assured that the state-owned utilities in mainland China would collaborate with the Hong Kong utilities to build new nuclear power plants in Guangdong with much of the electricity reserved for Hong Kong, as with the current Daya Bay nuclear power plant. It is possible that a new plant would have to be built within Hong Kong's territory, and this option would face strong opposition from the local population.

But even two new nuclear power plants would only supply about half of the current electricity consumption in the city beyond 2035, and many current patterns of consumption would have to be abandoned or greatly reduced. The electrified train system is highly efficient at present, and will have to be prioritized, along with basic functions such as water pumps and sewage systems. Wastage in the use of electricity in other activities in Hong Kong is substantial, and rising costs for electricity will squeeze out a lot of this wastage. But Hong Kong's commerce runs on high electricity consumption for offices, advertising, workstations, and communications, and Hong Kong's residential buildings are full of flat-screen TVs and household appliances. Much of this consumption and lifestyle will not survive the major 
reductions in electricity supply which are inevitable during this century.

Food for the city is the second major long-term problem beyond fossil fuels. Hong Kong's daily food consumption as of 2016 included 860 tons of rice, 2300 tons of vegetables, 4200 pigs, 48 cattle, and 22 tons of poultry, mostly chickens [89]. Hong Kong also produces about 3500 tons of fish through local aquaculture, mostly in fish ponds, and lands about 143,000 tons of wild-capture fish, mostly from far outside Hong Kong's territorial waters, some of which is consumed locally and some processed and exported. Hong Kong farms produce most of the chickens consumed locally, but only $2 \%$ of the vegetables, and none of the rice and other grains.

This is a huge change from the period after World War II, when Hong Kong produced most of the vegetables and some of the grains consumed by the 1.5 million inhabitants in the early 1950s, and when the local fishery could supply the population with fish from the waters around the city. The agricultural land in Hong Kong was mostly in the so-called New Territories, which comprised most of the land area of Hong Kong and included innumerable fields and small villages. Much of that territory has since been covered with buildings and roads as Hong Kong planners developed "new towns" in previously rural areas to accommodate the growing population.

There are still many small farmers operating in the New Territories, with about 2000 vegetable farms and several dozen poultry farms, occupying about $7 \mathrm{~km}^{2}$ out of the territory's total land area of $1100 \mathrm{~km}^{2}$, but their output would barely feed the New Territories villages, let alone the growing cities. Recently, the Hong Kong government proposed to establish an "Agriculture Park" on about $0.8 \mathrm{~km}^{2}$ in the New Territories to foster high-tech and sustainable farming, but this plan is seen by many farmers and local food activists as designed to allow the government to move some of the remaining farmers onto that small plot of land and release those current farm patches for further urban development [85].

In the 1980s, as the borders with China opened up and Hong Kong increasingly imported cheaper Chinese agricultural products, Hong Kong began to depend on mainland China for most of its food, delivered in trains, trucks, and coastal ships. During this period, the population's growing affluence, as Hong Kong industrialized, also led to imports of a wide range of foods from around the world-fruit, vegetables, dairy products, and meat from Australia, the USA, Brazil, the Netherlands, the UK, Southeast Asia, and many other countries, delivered in ships and by air. Once the food arrives in Hong Kong, it is distributed around the territory in trucks, running on gasoline or diesel fuel. What happens, as Alice Friedemann expresses this problem [24], "when the trucks stop running"?
Hong Kong depends on trucks, ships, and planes for transportation into the territory of food, consumer goods, and people, mostly tourists. The electrified trains (subways and light-rail) carried an average of 4.7 million passengers per day as of 2016 [85], and could be sustained with electricity from one or two nuclear power plants, but they carry only a fraction of the transportation load. The 13,000 busses, burning gasoline or diesel fuel, carry another several million passengers daily, but they do not carry goods or food. Food and consumer goods are distributed around the territory by about 113,000 light trucks, or "goods vehicles," also burning fossil fuels, which constantly crowd the streets and alleys of the city [90]. The main roads also carry a large number of trucks from mainland China bringing mainland-produced food and goods into Hong Kong every day across the land border. It appears to be impossible to replace these essential modes of transport with electric vehicles. There is also no possible source of biofuels in the region which could keep all of these vehicles operating without fossil fuels. Some heavy goods and foods arrive in Hong Kong in ships burning bunker oil, and eventually these arrivals of goods by ship will dwindle, as the fuel for powering these ocean-traveling cargo ships becomes increasingly costly or unavailable.

In regard to tourism and air travel, Hong Kong's international airport handles about 1000 flights per day, landing or departing more than 72 million passengers ("passenger throughput") during 2017 along with about 5 million tons of cargo [91], including goods and luxury foods from around the world, as well as baggage and mail. The airport employs about 73,000 staff, and these arrivals and related revenue for the city support many other jobs and services outside the airport. If the analysis above is correct, in regard to the poor prospects for mass air travel beyond fossil fuels, this major international airport will not have much use by the late twenty-first century. Most of the resulting employment, service industries, and revenues will disappear, and the airport will be very quiet except for a smaller number of propeller-driven aircraft mostly operating on biofuels or liquid fuels derived from coal.

In some cities, bicycles can carry a substantial part of the load for commuting and distribution of goods, but unlike in many cities in mainland China [92], there is virtually no bicycle-commuting or bike-sharing in Hong Kong. At present, with the streets congested with busses, trucks, cars, and taxis, it would be impossible at any time in the near future to make room for safe bicycle traffic on most of these roads, and there is virtually no public support or advocacy for increased use of bicycles, except for recreational uses in some areas along the waterfront [93]. In any case, many residential buildings are in hilly areas which would make bicycle transport difficult except for the hardiest cyclists. 
Bicycles and tricycle carts may eventually become more prevalent for commuting and for transporting goods and food in Hong Kong, as a result of the inevitable future decline of truck traffic as fossil fuels are depleted and become increasingly costly. Bicycle lanes may eventually be added to roads and highways. But this would only be a possible solution to the food-distribution problem for a much smaller population.

To summarize, Hong Kong could sustain most of the current electrification of the city into at least the 2080s or 2090s if two new nuclear power plants are built by about 2040, and if natural gas supplies and at least some coal can be imported over the same period. But it will be impossible to sustain the current population of 7.4 million, even at a lower standard of living, as oil, natural gas, and good-quality coal are depleted and eventually unavailable. Food provision from the immediate hinterlands of the city could not feed more than a small fraction of this population, even if all parks, green spaces, golf courses, and hillsides are converted to food production.

Food could be floated down the Pearl River on barges from the agricultural regions in Guangdong Province; the river enters the sea just south of the city. But much of the agricultural land in the Pearl River Delta has already been covered with factories, shopping malls, highways, and residential subdivisions, during the explosive economic growth in the province over the past three decades. If food from overseas and from other parts of China cannot easily reach Guangdong beyond fossil fuels, there will not be much surplus food to send down the river to Hong Kong. In any case, there is no way to transport enough food and consumer goods into and around the territory for such a large population without the 113,000 fossil fuel-powered trucks which currently keep each densely populated district in Hong Kong supplied with the essentials.

However, the late twenty-first century is far beyond the planning horizons of government, academics, think tanks, NGOs, and local political parties. Despite some attempts to raise the issue of longer-term energy depletion in local discourse (e.g., by a local peak oil advocacy group formed in 2007, and by a few academics, e.g., [94, 95]), the eventual loss of fossil fuels in the city's energy mix, and the likely consequences for the city's population, receive almost no attention from planners, politicians, or NGOs [83]. The city is drifting-unaware, preoccupied with current issues, complacent, disbelieving, or uncaring - toward a very different future.

The inevitable shrinking and possible collapse of Hong Kong's economy and the resulting decline to a more sustainable population will probably occur over a number of decades. Population decline will be facilitated by emigration, as Hong Kong people who can afford to do so move to countries such as Canada, Australia, and New
Zealand. Hundreds of thousands of Hong Kong citizens emigrated to these countries in the 1980s and 1990s, seeking political and economic security prior to China's recovery of sovereignty over the territory in 1997. Many of them returned to work in Hong Kong after 1997, while holding overseas citizenships, when it became apparent that Hong Kong was still economically vibrant. But their children and grandchildren will emigrate again if they can still do so. Many of the Hong Kong workingclass population who do not have such options will move into smaller towns and villages in mainland China where primary occupations and cheap food are still available. But even these emigrations out of Hong Kong may be insufficient to get Hong Kong down to a sustainable population, and considerable hardship and reductions of per capita food consumption are a very likely outcome for most of the remaining population in the territory.

What would be a sustainable population for Hong Kong beyond fossil fuels? It depends on many factors, including the possible revival of the local fishery, the amount of arable land which is still recoverable for agriculture in the late twenty-first century, and the ability of the population to return to manufacturing of craft goods which they could trade into Guangdong and up and down the coast of China in return for food and other goods. But it is unlikely that Hong Kong could sustain more than a fraction of its current population of 7.4 million people, beyond fossil fuels.

\section{Vancouver, B.C., Canada}

Vancouver, the most densely populated city in Canada, has a population of more than 630,000 in an area of about $114 \mathrm{~km}^{2}$. It sits within a "greater Vancouver" metropolitan area of about 2.5 million people, which includes 21 municipalities spread over $2900 \mathrm{~km}^{2}$, mostly on the major river deltas to the east and south of the city. When the city of Vancouver was incorporated in the 1880 s, local industry was mainly focused on the processing of wood from the province's vast forests, but after the cross-Canada railroad was completed during the same decade, the city became a major port, now accommodating more than 3000 ships each year, for exports of coal, forest products, grain, and minerals, most of which arrive at the port by train, and for imports from the USA and East Asia of consumer goods and other manufactured items which are carried by truck and rail from the port into the interior of the country.

The city has a mild climate by Canadian standards, and a good supply of water from rain-fed reservoirs and from the Fraser River which flows out of the mountains to the sea on the southern edge of the city. It is bounded on the north by mountains and a major inlet, on the west by the ocean, and on the south by the river. The 
mountains, ocean, mild climate, and large parks have made the city a major tourist destination.

From the point of view of sustainability, Vancouver's geographical location has allowed the city to get nearly all of its electricity from large hydroelectric dams built since the 1960s in the sparsely populated mountains and valleys in the interior of the province. Apart from the normal deteriorations in large dams (silting, settling and cracking of concrete, etc.), the shrinking of snowpack and glaciers in the interior of the province may eventually reduce the supply of water for the reservoirs behind these dams. But if they are well-maintained and the turbines serviced and replaced as needed, these dams may be able to electrify the city into the twenty-second century.

The urban core of Vancouver features forests of high-rise residential buildings. However, the suburbs and satellite towns have spread over a much larger area outside the urban core, and now cover much of the highly fertile river delta behind the city. Outside the densely populated urban core areas, the city and the surrounding municipalities are mainly comprised of low-rise residential and commercial areas, and the population in most of those areas is highly car-dependent for commuting and shopping. Electric trolley busses operate on some of the urban streets, and there is an electrified light-rail system running through several of the urban districts, with plans for expanding electrified mass transit along some routes, but even after such expansions, the electrified transit system can serve only a small fraction of the urban and suburban population. The rest must depend on cars and non-electrified busses to get around the $2300 \mathrm{~km}$ of city streets and the extensive road networks in the satellite towns. The urban core of Vancouver is walkable, and use of bicycles for commuting is possible, and apparently growing as bike lanes are added to major roads in the city, although bikes are still mostly used for recreation. Vancouver is the most bike-friendly major city in Canada. But most of the population would not be able to commute, shop, or get food using only bikes.

Some of the food supply for the city and the surrounding municipalities comes from the fertile river delta to the east and southeast of the city, but most of the food comes from the USA in trucks, from interior regions of Canada in trucks and by rail, and from overseas by air and in ships. Urban horticulture has been increasing in the city, with some support from the Vancouver City Council, but its contribution to the food supply for the city is still negligible. There is no possibility of feeding 2.5 million people in the Greater Vancouver region with food produced only in the rural hinterland of the city and its surrounding municipalities.

To summarize, because of its geographical location and advantages, Vancouver will be able to maintain the supply of electricity to the city into the twenty-second century. This makes it a favored location for all of the activities and functions which depend on a reliable supply of electricity. However, the depletion and eventual disappearance of fossil fuels will lead to progressively higher costs for importing food into the city by truck and distributing it among the many low-rise residential districts. Eventually, by sometime in the latter half of this century, nearly every substantial green space in the city, including the suburban golf courses, will have been converted to the production of vegetables and other foods. Tourist arrivals by air and in cruise ships will dwindle, only partially replaced by tourists coming to the city in trains from the south and the east. The forests within reach of the city will probably come under increasing pressure, for fuel-wood and for construction, and in the longer term, for producing wooden boats and ships to meet growing demand for these efficient forms of transportation.

Politically, Vancouver has had a long history of labor activism, vigorous environmental NGOs, bold academic research, and liberal politics [96]. There could be plenty of civic energy available for developing far-sighted plans and visions for the city, and for supporting policies to work toward those visions, as in cities such as Gothenburg with its 2050 Project [97]. But the gaps between wealthy local elites living in Vancouver's exclusive neighborhoods, and much of the working population living in most of the rest of the city, may lead to political conflicts and disruptions. In any case, the current mix of occupations in the economy of the Vancouver region almost certainly cannot be sustained beyond fossil fuels. The urban population will shrink as people migrate out into the hinterlands in the Fraser River delta, nearby islands, and the interior of the province, to work in small-scale farming, fishing, forestry, and local crafts.

It is possible that the reliable supply of electricity will lead to the transfer into Vancouver, from other cities, of functions which cannot be sustained in those cities because they lack Vancouver's hydroelectric assets. The city could become a kind of "electricity oasis," maintaining communications with other "electricity oases" as long as undersea cables and satellite communications continue to operate. The local universities will benefit greatly from continued reliable electricity, compared to universities in other cities which lose continuous and reliable electrification. Although there are no massive unsustainable megacities near Vancouver, and no nearby heavily populated regions which are likely to suffer environmental or economic collapse, there may be some migration into the city from the east and the south to take advantage of its still-electrified economy and services. So, the population may not shrink as much as we would expect from the loss of mass tourism and the great reductions in the import-export functions of the city. But 
the supply of food for the city will be a critical issue, and will probably force substantial net out-migration from the city even under the best scenarios.

What would be a sustainable population for Vancouver beyond fossil fuels? Again, the answer depends on the initiatives of city dwellers in returning to and developing primary and secondary industries and local trade networks, the revival of food production on the river delta and in the parks and green spaces in the city, and the extent to which the city can avoid destructive local conflict. But it seems very likely that the current population-630,000 in the city and 2.5 million in the greater metropolitan region-cannot be sustained beyond fossil fuels.

These two case studies illustrate how a major city's "sustainability" has to be assessed in a multi-factor analysis which highlights the resources and vulnerabilities of a city beyond fossil fuels. Cities which do not have most of the features required for some level of sustainabilityand this applies to almost all major cities-will face difficult contractions and struggles in the latter half of this century. But cities are also embedded in larger-scale systems. How will these larger-scale interactions affect the fates of cities beyond fossil fuels?

\section{Local and regional politics}

Cities cannot solve all of their problems in getting energy, food, and goods into the city in isolation from surrounding towns and cities. If nearby cities compete aggressively with each other for local resources such as water, arable land, food, and forests, it is likely that this will seriously deplete and degrade these resources, including through classic "tragedy of the commons" exploitation of the remaining natural assets. Open conflict, including violence, is also possible and perhaps inevitable as shortages become more acute. Regional governance, with participation from each city and town in the region, is important for reducing this kind of destructive competition and for strengthening collaboration, consultation, and joint research to work toward sustainable management of each resource (as argued by a number of analysts, e.g., [5]).

Europe seems to have supported innovative regional governance and collaborations. Examples include the Council of European Municipalities from the 1950s, and its successors and related initiatives in the Council of European Municipalities and Regions in the 1980s, the Aalborg Charter in 1994, the "Covenant of Mayors" in 2008, described as "the European movement of local and regional authorities committing to increasing energy efficiency and using renewable energy sources on their territories" [98], and the Basque Declaration after the 8th European Conference on Sustainable Cities and Towns in 2016 [99].
The "greater metropolitan areas" which have been institutionalized around major cities in North America are not usually large enough to include the rural hinterlands and the nearby towns and smaller cities, which would have to be included in strategies for sustainable management. The "municipalities" in China such as Shanghai, Nanjing, and Chengdu, which are large enough to include the urban core and also the towns, villages, and agricultural districts in the hinterlands of the urban core [69] are a better governance model than "greater metropolitan areas" in North America. However, it will be important to develop links between comparably sized cities within a region, that is, to reach beyond the immediate hinterlands of each city.

There will be resistance from landowners, developers, and allied elites if city coalitions try to restrict hinterland land uses, especially if those uses are profitable. The political process of overcoming this resistance and bringing rural and small-town constituencies into regional planning will be difficult and contentious in many regions, but in the longer-term, essential. As in the co-management of fisheries to achieve more sustainable use of a resource, robust social capital is important for collective conservation of the resource, but strong leadership is also essential [100]. Regions in which the political culture nurtures and supports such leadership will have a greater chance of success in the longer term in managing the difficult transitions to sustainable regional economies. Some regions will fail to achieve these transitions. At larger scales, the long-term problems will be even more serious.

\section{Contraction, conflict, and collapse}

Political and economic disruptions and decline at much larger scales than cities or city regions are inevitable. The unprecedented exchanges of goods and people across oceans and continents over the past 100 years only became possible with the concentrated energy from fossil fuels, and will be unsustainable without it. The declines in global economic trade may have a large impact on even the most proactive and progressive cities, which will be unable to insulate themselves from such developments. But future contractions of the global economy will also undermine large political units such as states, whose authority and potency is based on the ability to collect surplus revenue from the populations within their boundaries, and to use coercion, and selective distribution of rewards, to enforce state-level decisions on local populations. What happens to state-level authority beyond fossil fuels?

Projections into the future are only considered feasible or credible by most scientists for on-going trends in which the causes and dynamics of change are understood well enough to make some medium-term predictions (e.g., in demography, or climate change). Few 
social scientists would try to predict the future social and political consequences of the on-going depletion of resources. Academic scholars addressing this kind of question have therefore turned from the future to the past, to analyze the historical decline and collapse of complex societies which have depleted their own resource base, or grown too large and complex to be sustained in the absence of further conquests, or failed to adapt to changing climatic conditions. Decline and collapse were sometimes accelerated by wars and civil conflicts. Joseph Tainter in The Collapse of Complex Societies [37], and Jared Diamond in Collapse: How Societies Choose to Fail or Succeed [82] devoted most of their analysis to historical cases of the disintegration or collapse of states, kingdoms, and empires, but at the end of each book, they suggest that contemporary societies face similar problems and may suffer similar outcomes.

Some analysts who work mostly outside academia have been more bold, and ventured to sketch political and social scenarios resulting from future economic decline. For example, Kunstler [31], Greer [33], and Heinberg [5, 20] have all predicted that the end of fossil fuels will lead to the decline and breakup of some state-level polities, and increasing devolution of authority to regional populations, especially where there are substantial cultural differences between these regional populations. The breakups of large state-level polities would be a consequence of their declining resources and inability to continue to project sufficient power and authority over aggrieved and restive regions.

Kunstler and Greer have also taken these projections into the realm of fiction, since novels provide more flexibility for exploring such scenarios. Kunstler sketched several possible local models of governance in these novels (e.g., [101-104]), including a theocratic religious commune, a semi-feudal estate in which a large-landowner employs and supervises landless workers and their families on his estates, and a township with elected office-holders which has to find ways to deal with the unavoidable relations with nearby theocracies and with powerful authoritarian rural landowners. It should not be assumed that a democratic local polity will turn out to be superior for the maintenance of a sustainable local economy to the non-democratic alternatives.

For future-oriented governance, which may involve sacrifices in the present for the sake of future generations, democratic participation may have advantages, as has been demonstrated experimentally [105] and in practice as in some of the urban-networks institutions developed in Europe. However, democratic polities may not be the only or even the best models for sustainable management of regional resources. In a poor region, when a polity becomes more democratic, it can actually increase the rate of depletion of local resources such as forests as politicians compete for the support of land-hungry rural voters [106].

In any case, governance is much more likely to be local and regional, as the capacity of a central state to project national authority declines. Political identities and allegiances are often local and regional. Many people identify strongly with their own city or town, and in some areas with their region, on the basis of local geography, shared social and political culture, and pride in local history. The identification with a local town or region can have a longer and deeper history than identification with the more recent nation states which now incorporate those towns and regions. This was expressed explicitly in the preamble to the Charter of European Cities and Towns Toward Sustainability: "We, European cities \& towns, signatories of this Charter, state that in the course of history, our towns have existed within and outlasted empires, nation states, and regimes and have survived as centres of social life, carriers of our economies, and guardians of culture, heritage and tradition." [italics added] [107].

Social ties and social capital can be particularly dense and strong in such areas. Increasing those ties and extending that social capital to nearby cities and towns, through collaborations and joint projects, can help to strengthen local and regional resilience. This is not, unfortunately, the only way in which local and regional societies might deal with the apparently inevitable economic and political crises which will emerge in the latter half of the twenty-first century.

There is an argument that liberal democracy, to the extent that it is devoted to realization of individual freedoms (including and especially freedom to consume), is simply not compatible with longer-term sustainability, since sustainability could not be achieved without imposing constraints on material consumption and hence on individual freedoms [108]. But these constraints will emerge also through rising costs and increasing scarcity. "Crisis-authoritarianism," as has often emerged even in democratic societies during wartime, is one of the likely future modes of governance. We cannot easily peer into this future, but there are disturbing historical precedents, which should add urgency to our preparations.

\section{Models and projections}

Social scientists should begin to imagine and describe some of the social and political scenarios which may evolve as the energy crisis increasingly affects societies at every scale. Only a few analysts have ventured into this kind of territory [5, 19, 31, 33, 34]. We need more of these kinds of scenarios to invigorate activism toward the best outcomes, and to help us think about and try to avoid the worst outcomes. 
There is also much work for courageous economic thinkers. One of the areas of research which should be expanded is the building of models in which the many economic sectors of a society are linked through causal chains of dependence, interdependence, and feedbacks. It should be possible to specify the sectors which are most directly affected and diminished by declines in cheap energy, and among those, which sectors will have the greatest impacts on other sectors. With depletion of fossil fuel-energy inputs or rising energy costs (i.e., reduced returns on investment to extract remaining fossil fuels) [109], how do rising energy costs ramify throughout the local and regional economy? Of course, there are other key resource-inputs from beyond the city region, and the energy inputs which make these flows of resources into the city possible can also be built into the models. These models will be not much better than "thinking tools" at first, but will be increasingly testable against real developments in various regions, as we enter the latter half of the twenty-first century.

Debates about the future of cities beyond fossil fuels will lead some analysts to investigate what is known about pre-industrial towns and cities. We can expect increasing interest in the discussions among historians, archeologists, and geographers about pre-industrial urban populations and economies. That research includes many studies of the relations between towns or cities and the hinterland populations which sustained them $[26,110]$. That research should and will be interesting to analysts trying to imagine the post-fossil fuels urban futures which will be inhabited by our children and grandchildren.

\section{Conclusions}

Ancient hydrocarbons have energized societies around the world for the past hundred years, facilitating explosive growth in global trade and food production, and massive increases in urban populations. Those fuels will be mostly gone by the last decades of the twenty-first century, at least for oil and gas. Renewables, new technologies, and increased efficiency in use of energy are important, but they can cover only a fraction of the energy gap in most cities as fossil fuels are depleted. It appears that it will not be possible to sustain the current populations of most major cities beyond fossil fuels. Although these are tentative conclusions, it is important to consider the consequences and the policy implications if these conclusions have some probability of being correct.

Feeding people in these cities would be increasingly troublesome. Food production and distribution for major cities currently relies heavily on fossil fuels-for fertilizer, harvesting, transportation, and refrigeration. Growing food through mechanized agriculture, and transporting vegetables, fruit, and meat over long distances into cities by trucks, ships, and planes, would become increasingly costly and difficult.

As fossil fuels are depleted, most of these cities would experience economic decline, deterioration of infrastructure, rising food costs, shrinkage in tertiary-sector occupations, falling standards of living, and growing poverty. Inevitably, the processes of urban decline will be messy and contentious, punctuated by radical movements, civic strife, and probably conflicts within and between some regions over resources.

Cities still thriving in the late 21st and early twenty-second century will be near rivers, lakes, or seacoasts, with intensively farmed land around the city. They will be small enough to provide most of their food from the surrounding region, and to provide electricity from nearby sources of renewable energy. They will also have solved the problem of getting food and other resources into and around the city without fossil fuels-powered trucks.

The use of renewable energy technologies to progressively replace fossil fuels for electricity will only be a temporary solution unless it is possible to manufacture, install, and maintain these highly engineered constructions using only renewable energy-powered systems. The long-term engineering problems have received almost no attention, but production of renewable energy-technologies using only renewable energy is certain to become one of the great scientific and technical challenges of the late twenty-first century.

It is certain that we will have to live without fossil fuels within a couple of generations, and that this will have a large impact on cities. But how that will play out in particular regions? There are many uncertainties. Not much work has been done on projections and likely sequences of change. As noted, the planning horizons of almost everyone involved in future-oriented policies extend only a few decades into the future, at most. We need much more work on longer-term models and scenarios, to invigorate planning, NGO activism, and the energies and hopes-and perhaps also the fears-of those who care about the futures of their cities.

\footnotetext{
Abbreviations

EROI: Energy return on investment, i.e., the net energy available after subtracting the costs (or alternatively, the energy, i.e., EROEI) expended in producing that energy; NGO: Non-government organization
}

\section{Acknowledgements}

The author would like to thank the reviewers, and other scholars who commented on these ideas after presentations and discussions at the recent "energy futures" conference in Finland, the Governance in Asia Research Centre at City University of Hong Kong, the Department of Geography and Resource Management at The Chinese University of Hong Kong, and the Global Institute of Sustainability at Arizona State University, with particular thanks to lan Lyne, Martin Painter, Rob Melnick, Bo Miao, Justin Robertson, Wanxin Li, and Charles Rhodes in Toronto. 


\section{Availability of data and materials}

All data and material are publicly available in the cited sources and websites.

\section{Author's contribution}

The author read and approved the final manuscript.

\section{Ethics approval \\ Not applicable.}

\section{Consent for publication}

Not applicable.

\section{Competing interests}

The author declares that he has no competing interests.

\section{Publisher's Note}

Springer Nature remains neutral with regard to jurisdictional claims in published maps and institutional affiliations.

Received: 14 May 2018 Accepted: 17 September 2018

Published online: 04 October 2018

\section{References}

1. Love T, Isenhour C (2016) Energy and economy: recognizing high-energy modernity as a historical period. Econ Anthropology 3:6-16

2. Day JW, Hall C (2016) America's most sustainable cities and regions. Springer, N.Y

3. Wang J, Feng L, Zhao L, Snowden S, Wang X (2011) A comparison of two typical multicyclic models used to forecast the world's conventional oil production. Energy Policy 39:7616-7621

4. Maggio G, Cacciola G (2012) When will oil, natural gas, and coal peak? Fuel 98(August):111-123

5. Heinberg R (2015) Afterburn: society beyond fossil fuels. New Society Publishers, Gabriola Island, B.C.

6. Heinonen S, Karjalainen J, Ruotsalainen J, Steinmüller K (2017) Surprise as the new normal-implications for energy security. Eur J of Futures Res 5:12

7. Meadows, DH, Meadows, DL, Randers, J, Behrens III, WW (1972) The limits to growth: a report for the Club of Rome's project on the predicament of mankind. New American Library

8. Edwards AR (2005) The sustainability revolution: portrait of a paradigm shift. New Society Publishers, Gabriola Island, B.C.

9. Ostrum E ((2009)) A general framework for analyzing sustainability of socioecological systems. Science 325(24 July):419-422

10. Owen D (2009) Green metropolis: why living smaller, living closer, and driving less are the keys to sustainability. Riverhead Books, N.Y

11. Glaeser E (2011) Triumph of the city: how our greatest invention makes us richer, smarter, greener, healthier, and happier. Penguin, N.Y

12. Odum HT, Odum E (2001) A prosperous way down: principles and policies. University Press of Colorado, Denver

13. Hoekstra AY, Wiedmann, TO (2014) Humanity's unsustainable environmental footprint. Science 344(6188):1114-1117

14. Inman M (2016) The oracle of oil. W.W. Norton, N.Y

15. Hughes JD (2013) A reality check on the shale revolution. Nature 494(February 21):307-308

16. Heinberg R (2013) Snake oil: how fracking's false promise of Pplenty imperils our future. Post carbon institute. Santa Rosa, Calif, In

17. Inman M (2014) The 'fracking' fallacy. Nature 516(December 4):28-30

18. Heinberg R (2003) The party's over: oil, war and the fate of industrial societies. New Society Publishers, Gabriola Island, B.C.

19. Heinberg R (2004) Powerdown: options and actions for a post-carbon world. New Society Publishers, Gabriola Island, B.C

20. Heinberg R (2011) The end of growth: adapting to our new economic reality. New Society Publishers, Gabriola Island, B.C.

21. Rubin J (2015) The carbon bubble: what happens to us when it bursts. Random House Canada, Toronto

22. Drews S, Miklós A (2016) Degrowth: a 'missile word' that backfires? Ecol Econ 126(June):182-187 https://doi.org/10.1016/j.ecolecon.2016.04.001

23. Rees WE (2012) Cities as dissipative structures: global change and the vulnerability of urban civilization. In: Weinstein MP, Turner RE (eds) Sustainability science: the emerging paradigm and the urban environment. Springer, N.Y, pp 247-273
24. Friedemann A (2016) When the trucks stop running: energy and the future of transportation. Springer, N.Y

25. Mohr S, Wang J, Ellem GK, Ward J, Giurco DP ((2015)) Projections of world fossil fuels by country. Fuel (141; February):120-135 https://doi.org/10.1016/j. fuel.2014.10.030

26. Mumford L (1961) The city in history. Penguin, N.Y

27. Deffeyes KS (2005) Beyond oil: the view from Hubbert's peak. Hill and Wang, N.Y

28. Urry J (2013) Societies beyond oil: oil dregs and social futures. Zed Books, London

29. Murray J, King D (2012) Oil's tipping point has passed. Nature 481, 26 Jan: 433-435

30. Patzek TW, Croft GD (2010) A global coal production forecast with multiHubbert cycle analysis. Energy 35(8):3109-3122

31. Kunstler JH (2005) The long emergency: surviving the end of oil, climate change, and other converging catastrophes of the twenty-first century. Grove Press, N.Y

32. Kunstler JH (2012) Too much magic: wishful thinking, technology, and the fate of the nation. Grove Press, N.Y

33. Greer JM (2008) The long descent: a user's guide to the end of the industrial age. New Society Publishers, Gabriola Island, B.C.

34. Greer JM (2014) Decline and fall: the end of empire and the future of democracy in $21^{\text {st }}$ century America. New Society Publishers, Gabriola Island, B.C.

35. Greer JM (2016) Dark age America: climate change, cultural collapse, and the hard future ahead. New Society Publishers, Gabriola Island, B.C.

36. Meadows D, Randers J, Meadows D (2004) Limits to growth: the 30-year update. Chelsea Green Publishing Co., Whyte River Junction, VT

37. Tainter J (1988) The collapse of complex societies. Cambridge University Press, Cambridge, MA

38. Jackson T (2011) Prosperity without growth: economics for a finite planet. Earthscan, London

39. Rubin J (2012) The end of growth. Random House Canada, Toronto

40. Hopkins R (2008) The transition handbook: from oil dependency to local resilience. Green Books, Totnes, U.K.

41. Troy A (2012) The very hungry city: urban energy efficiency and the economic fate of cities. Yale University Press, New Haven

42. Clack C et al (2017) Evaluation of a proposal for reliable low-cost grid power with 100\% wind, water, and solar. PNAS 114(26):6722-6727

43. Jackson R, Canadell J, Le Quere C, Andrew R, Korsbakien J, Peters G, Nakicenovic N et al (2016) Reaching peak emissions. Nature Climate Change 6:7-10 Figure 3

44. Liu, C (2018) For the UAE, are renewables the new oil? South China Morning Post, April 9. (http://www.scmp.com/week-asia/business/article/ 2140281/uae-are-renewables-new-oil, Accessed 10 April 2018)

45. Bloomberg NEF (2018) New energy outlook 2018 (at https://bnef.turtl.co/ story/neo2018?teaser=true) Accessed 2 Aug 2018

46. Hohmeyer, O (2018) 100\% renewable energy for Europe. Presented at the 'energizing futures' conference, Tampere, Finland, June 14, 2018

47. Monbiot, G (2006) Heat: how to stop the planet from burning. Doubleday Canada

48. Rodea DC, Fischbecka PS, Páez AR (2017) The retirement cliff: power plant lives and their policy implications. Energy Policy 106:222-232

49. Greenworldinvestor (2016) Wind turbines theft becomes a multi-million dollar industry in India (http://www.greenworldinvestor.com/2013/08/20/ wind-turbines-theft-become-a-multi-million-dollar-industry-in-india/, retrieved July 6, 2016)

50. Honeywell (2016) Theft in the wind industry (https://www.security. honeywell.com/uk/documents/Theft-in-the-Wind-Industry_0712.pdf, retrieved July 6, 2016)

51. Plumer B (2018) Kelp farms and mammoth windmills are just two of the government's long-shot energy bets. New York Times (March 16)

52. National Public Radio (2011) A nuclear powered world. (at: http://www.npr. org/2011/05/16/136288669/a-nuclear-powered-world) Accessed 1 May 2018

53. Lovelock J (2006) The revenge of gaia: why the earth is fighting back, and how we can still save humanity. Allen Lane (Penquin), London

54. Hansen J (2009) Storms of my grandchildren: the truth about the coming climate catastrophe and our last chance to save humanity. Bloomsbury, N.Y

55. World Nuclear Association (2018) Fast neutron reactors. (accessed Aug. 3 at: http://www.world-nuclear.org/information-library/current-and-futuregeneration/fast-neutron-reactors.aspx) 
56. Schneider M, Froggatt A, Thomas S (2011) Nuclear power in a postFukushima world. Mycle Schneider Consulting, WorldWatch Institute

57. Pfeiffer D (2006) Eating fossil fuels: oil, food, and the coming crisis in agriculture. New Society Publishers, Gabriola Island, B.C.

58. Jackson RB, Canadell JG, Le Quéré C, Andrew RM, Korsbakken Jl, Peters GP, Nakicenovic N (2016) Reaching peak emissions. Nat Clim Chang 6:7-10

59. Bristol Green Capital (2011) Who feeds Bristol: towards a resilient food plan. Bristol, U.K (short version available at: www.bristol.gov.uk/documents/20182/ 32619/Who-feeds-Bristol-report.pdf. Accessed 25 Sept 2018

60. Morgan K (2013) The rise of urban food planning. Int Plan Stud 18(1):1-4

61. Elton S (2013) Food for a finite planet. University of Chicago Press

62. Gallaher C, Kerr J, Mjenga M, Karanja N, WinklerPrins A (2013) Urban agriculture, social capital, and food security in the Kibera slums of Nairobi, Kenya. Agric Hum Values 30(3):389-404

63. Ackerman $\mathrm{K}$ et al (2011) The potential for urban agriculture in New York City: growing capacity, food security \& green infrastructure. https://doi.org/ 10.13140/2.1.4748.7683

64. Foderaro, L (2012) In book bag, more garden tools. New York Times 23 Nov

65. Owen D (2011) The conundrum: how scientific innovation, increased efficiency, and good intentions can make our energy and climate problems worse. Riverhead Books, N.Y

66. Preiss P, Charão-Marques F, Wiskerke J (2017) Fostering sustainable urbanrural linkages through local food supply: a transnational analysis of collaborative food alliances. Sustainability 9:1155 https://doi.org/10.3390/ su9071155

67. Haas W, Andarge H (2017) More energy and less work, but new crises: how the societal metabolism-labour nexus changes from agrarian to industrial societies. Sustainability 9:1041 https://doi.org/10.3390/su9071041

68. Lang G (2002) Deforestation, floods, and state reactions in China and Thailand. In: Mol A, Buttel F (eds) The environmental state under pressure. Elsevier Science, N.Y, pp 195-220

69. Lang G, Miao B (2013) Food security for China's cities. Int Plan Stud 18(1):116

70. Sripad S, Viswanathan V (2017) Performance metrics required of nextgeneration batteries to make a practical electric semi truck. ACS Energy Lett 2:1669-1673

71. Guttenberg M, Sripad S, Viswanathan V (2017) Evaluating the potential of platooning in lowering the required performance metrics of li-ion batteries to enable practical electric semi-trucks. ACS Energy Lett. 2:2642-2646

72. Shove E et al (2015) Conceptualizing connections: energy demand, infrastructures and social practices. Eur J Social Theory 18:274-287 https:// doi.org/10.1177/1368431015579964

73. Radison, T (2013) 8 innovations in road surface products and techniques. On-site: Canada's Construction Magazine Since 1957. March 1. (https://www. on-sitemag.com/features/8-innovations-in-road-surface-products-andtechniques/, Accessed 4 Mar 2018)

74. Statista (2018) Total fuel consumption of commercial airlines worldwide between 2005 and 2018 (in billion gallons) (https://www.statista.com/ statistics/655057/fuel-consumption-of-airlines-worldwide/, Accessed 1 May 2018)

75. Lufthansa ((2012)) Use of sustainable biofuels for aviation: requirements of the airline industry. Presentation on Febr. 8, 2012, to ISCC general assembly. In: Brussels

76. Wu W et al (2009) Potential land for plantation of jatropha curcas as feedstocks for biodiesel in China. Science China-Earth Sciences. https://doi. org/10.1007/s11430-009.0204-y

77. Kant P, Wu S (2011) The extraordinary collapse of jatropha as a global biofuel. Environ Science Techn 45:7114-7115

78. Gelfand I, Sahajpal R, Zhang X, Isaurralde R, Gross K, Robertson G ((2013)) Sustainable bioenergy production from marginal lands in the US. Midwest Nature 493(24 Jan.):514-517

79. Green Car Congress (2018) ASTM greenlights ethanol as feedstock for alcoholto-jet synthetic fuels; blend level up to 50\%. 16 April (at: http://www. greencarcongress.com/2018/04/20180416-atj.html) Accessed 31 July 2018

80. Kuhlman A (2006) Peak oil-and the collapse of commercial aviation? Airways Magazine 13(5):12-19

81. Taylor, T (2011) On small farms, hoof power returns New York Times, May 3

82. Diamond J (2005) Collapse: how societies choose to fail or succeed. Penguin, N.Y

83. Leung A, Matthew I, Burke A (April 2017) Cui J (2017) The peak oil and oil vulnerability discourse in urban transport policy: a comparative discourse analysis of Hong Kong and Brisbane. Transp Policy. https://doi.org/10.1016/j. tranpol.2017.03.023

84. Sim T, Wang D, Han Z (2018) Assessing the disaster resilience of megacities: the case of Hong Kong. Sustainability 10:1137 https://doi.org/10.3390/ su10041137

85. Gottlieb R, Ng S (2017) Global cities: urban environments in Los Angeles, Hong Kong, and China. The MIT Press, Cambridge, MA

86. Hong Kong Census and Statistics Department (2018) Hong Kong energy statistics: 2017 Annual Report

87. Reuters (2016) Indonesia could deplete coal reserves by 2033 - PWC. Reuters, March 7 (at: https://www.reuters.com/article/indonesia-coal/ indonesia-could-deplete-coal-reserves-by-2033-pwc-idUSL4N16F4C4) Accessed 28 Mar 2018

88. MTR Corporation (2016) Sustainability report: environment (at: https://www. mtr.com.hk/en/corporate/sustainability/2016rpt/pdf/Environment.pdf) Accessed 21 July 2018

89. Agriculture F, Dept C, Hong Kong Government (2017) Hong Kong: the facts: agriculture and fisheries. May 2017 (at: https://www.gov.hk/en/about/ abouthk/factsheets/docs/agriculture.pdf) accessed (27 Mar 2018)

90. Transport Department, Hong Kong Government, 2018: Section 4, Vehicle registration, licensing, and inspection statics. http://www.td.gov.hk/ filemanager/en/content 4862/table41s.pdf, Accessed 28 Apr 2018.

91. Hong Kong International Airport: Factsheet (2018) (https://www. hongkongairport.com/iwov-resources/file/the-airport/hkia-at-a-glance/factsfigures/HKIA_FactSheet_2018_EN.pdf)

92. Qiu L, He L (2018) Bike sharing and the economy, the environment, and health-related externalities. Sustainability 10:1145 https://doi.org/10.3390/ su10041145

93. Tan H ((2017)) The politics of urban cycling mobility: an analysis of the social and political change in Hong Kong and Guangzhou. PhD dissertation submitted to the Dept. of public policy. In: City University of Hong Kong

94. Lang G (2008) View from the peak. South China Morning Post, March 10:A15

95. Lang G (2017) Viable future lies beyond oil, coal, and gas. South China Morning Post, May 2:A11

96. Weiss KR ((2016)) Vancouver's green dream. Science 352(20 May):918-921

97. Bibri SE (2018) Backcasting in futures studies: a synthesized scholarly and planning approach to strategic smart sustainable city development. Eur J of Futures Res 6(13) https://doi.org/10.1186/s40309-018-0142-z

98. Council of European Municipalities and Regions (2011) Local and regional government in Europe: structures and competences (http://www.ccre.org/docs/ Local_and_Regional_Government_in_Europe.EN.pdf, Accessed 1 Apr 2018)

99. Basque Declaration (accessed May 2, 2018 at: http://www.sustainablecities. eu/fileadmin/repository/Basque_Declaration/Basque-Declaration-ENGLISHWWW.pdf)

100. Guitierrez N, Hilborn R, Defeo O ((2011)) Leadership, social capital and incentives promote successful fisheries. Natusre 470(17 Febr):386-389

101. Kunstler JH (2008) World made by hand. Grove Press, N.Y

102. Kunstler JH (2010) The witch of Hebron. Grove Press, N.Y

103. Kunstler JH (2014) A history of the future. Atlantic Monthly Press, N.Y

104. Kunstler JH (2016) The harrows of spring. Atlantic Monthly Press, N.Y

105. Hauser O, Rand D, Peysakhovich A, Nowak M ((2014)) Cooperating with the future. Nature 500(10 July):220-223

106. American Geophysical Union, 2018. 'Elections may be a catalyst for deforestation, new research suggests'. January 10, 2018. (at: https://phys. org/news/2018-01-elections-catalyst-deforestation.html\#j(p) Accessed 10 Feb 2018

107. Charter A (1994) Charter of European cities \& towns towards sustainability European conference on sustainable cities \& towns in Aalborg, Denmark. (at: http://www.sustainablecities.eu/fileadmin/repository/Aalborg_Charter/ Aalborg_Charter_English.pdf) Accessed (19 April 2018)

108. Blühdorn I (2013) The governance of unsustainability: ecology and democracy after the post-democratic turn. Environ Pol 22:16-36

109. Guilford MC, Hall CAS, O'Connor P, Cleveland CJ (2011) A new long term assessment of energy return on investment (EROI) for US oil and gas discovery and production. Sustainability 3(10):1866-1887

110. Storey GR (ed) (2006) Urbanism in the preindustrial world: cross-cultural approaches. University of Alabama Press, Tuscaloosa 